\title{
Składka w polskim i niemieckim systemie ubezpieczenia zdrowotnego ${ }^{1}$
}

\section{The contribution in the Polish and German medical health care systems}

Streszczenie. Niniejsze opracowanie dotyczy problematyki konstrukcji prawnej składki w polskim i niemieckim systemie ochrony zdrowia. Ustalono w nim najważniejsze różnice i podobieństwa zachodzące pomiędzy polską i niemiecką wersją składki na ubezpieczenie zdrowotne. Do podobieństw zaliczono m.in.: istotne znaczenie fiskalne oraz cel obu danin, nierównomierne rozłożenie ciężaru ubezpieczeniowego. Jako różnice w konstrukcji prawnej badanych danin publicznych wskazano: wysokość stawki składki, brak ograniczenia podstawy wymiaru polskiej składki zdrowotnej oraz możliwość odliczenia części składki od podatku dochodowego. Sformułowano także wnioski de lege ferenda.

Słowa kluczowe: składka; system ochrony zdrowia.

1 Opracowanie przygotowane w ramach projektu pt. „Źródła finansowania ochrony zdrowia w Polsce - aspekty prawne” finansowanego w konkursie PRELUDIUM 8 organizowanym przez Narodowe Centrum Nauki w Krakowie (nr wniosku 2014/15/N/HS5/01735). 


\begin{abstract}
This study deals with the problems of legal construction of the contribution in the Polish and German medical health care systems. The major differences and similarities have been established between the Polish and German versions of the health insurance contribution. The similarities comprise of among others: significant fiscal meaning and a purpose of both levies as well as an unbalanced distribution of the insurance burden. As the differences in the legal construction of the public levies under examination the following have been indicated: the contribution rate, the lack of limits on the Polish health insurance contribution rate assessment basis and the possibility of deducting a part of contribution from an income tax. Also de lege ferenda notions have been presented.
\end{abstract}

Keywords: contribution; health care system.

\title{
1. Wprowadzenie
}

Ustawą z dnia 6 lutego 1997 r. o powszechnym ubezpieczeniu zdrowotnym $^{2}$ istotnie zmieniono model organizacji i finansowania ochrony zdrowia w Polsce ${ }^{3}$. Na mocy art. 171 u.p.u.z. uchylono funkcjonującą od 1933 r. ustawę o ubezpieczeniu społecznym ${ }^{4}$ i wprowadzono model powszechnego ubezpieczenia zdrowotnego. Tym samym ustawodawca zrezygnował z obowiązującego przez prawie 50 lat budżetowego systemu organizacji i finansowania ochrony zdrowia.

Niemiecki system ochrony zdrowia funkcjonuje w oparciu o ustawowe ubezpieczenie zdrowotne (Gesetzliche Krankenkversicherung $G K V)$ i jest nazywany modelem Bismarcka. Tego rodzaju model organizacji i finansowania ochrony zdrowia nieco zmodyfikowany występuje obecnie w wielu krajach Unii Europejskiej, m.in. w Holandii, Belgii, Austrii i Francji ${ }^{5}$.

\footnotetext{
Dz.U. Nr 28, poz. 153 ze zm. (dalej: u.p.u.z).

Ustawa po długim okresie vacatio legis weszła w życie dopiero 1 stycznia $1999 \mathrm{r}$.

4 Ustawa z dnia 28 marca 1933 r. o ubezpieczeniu społecznym (Dz.U. RP Nr 51, poz. 936 ze zm.).

5 M. Dziubińska-Michalewicz, Systemy ubezpieczeń zdrowotnych w wybranych krajach Unii Europejskiej (Francji, RFN, Szwecji, Wielkiej Brytanii). Raport nr 168, http://biurose.sejm.gov.pl/teksty/r-168.htm, (dostęp: 15.01.2017 r.).
} 
Głównym źródłem finansowania polskiego i niemieckiego systemu ochrony zdrowia jest składka ubezpieczeniowa. Obok podobieństw pomiędzy składką w niemieckim ustawowym ubezpieczeniu zdrowotnym a składką funkcjonującą w ramach polskiego powszechnego ubezpieczenia zdrowotnego istnieje także szereg różnic. Uzasadnione wydaje się zatem podjęcie próby ich zbadania.

\section{Polski system finansowania ochrony zdrowia}

Konstytucja Rzeczypospolitej Polskiej ${ }^{6}$ w art. 68 ust. 1 i 2 przyznaje każdemu prawo do zdrowia i jednocześnie nakłada na władze publiczne obowiązek zapewnienia równego dostępu do świadczeń opieki zdrowotnej finansowanych ze środków publicznych. Przepisy Konstytucji RP nie narzucają jednak warunków oraz zakresu udzielania świadczeń zdrowotnych, odsyłając w tym przypadku do ustawy zwykłej. Brak jest także regulacji konstytucyjnych dotyczących rodzajów źródeł, z których może być finansowany system ochrony zdrowia. To, czy świadczenia zdrowotne będą finansowane bezpośrednio z budżetu państwa, czy w oparciu o model ubezpieczeniowy z planu finansowego instytucji zarządzającej powszechnym ubezpieczeniem zdrowotnym, nie jest regulowane konstytucyjnie. Zostało pozostawione do rozstrzygnięcia ustawodawcy zwykłemu.

Podstawowym dla struktury organizacyjnej, funkcjonowania i finansowania polskiego modelu ochrony zdrowia aktem prawnym jest ustawa o świadczeniach opieki zdrowotnej finansowanych ze środków publicznych ${ }^{7}$. Jej przepisy określają warunki i zakres świadczeń zdrowotnych, o których mowa w art. 68 ust. 2 Konstytucji RP, a także zasady i tryb ich

$6 \quad$ Konstytucja Rzeczypospolitej Polskiej z dnia 2 kwietnia 1997 r. (Dz.U. Nr 78, poz. 483 ze zm., dalej: Konstytucja RP).

7 Ustawa z dnia 27 sierpnia 2004 r. o świadczeniach opieki zdrowotnej finansowanych ze środków publicznych (Dz.U. z 2016 r. poz. 1793 ze zm., dalej: u.ś.o.z). 
finansowania. Nie bez znaczenia pozostają także przepisy ustawy o działalności leczniczej ${ }^{8}$.

Podmiotem odpowiedzialnym za funkcjonowanie polskiego systemu ochrony zdrowia jest Narodowy Fundusz Zdrowia ${ }^{9}$. Wynika to z katalogu nałożonych na niego zadań, o którym mowa w art. 97 u.ś.o.z. Istotne znaczenie dla organizacji modelu ubezpieczeniowego mają także jednostki samorządu terytorialnego ${ }^{10}$ oraz organy administracji rządowej ${ }^{11}$.

W polskim systemie ochrony zdrowia, opartym o powszechne ubezpieczenie zdrowotne, składka ubezpieczeniowa nie jest jedynym źródłem finansowania. Zadania publiczne z zakresu ochrony zdrowia finansowane są także z budżetu państwa oraz budżetów samorządowych ${ }^{12}$. Z budżetów j.s.t. dokonywane są przede wszystkim wydatki na finansowanie działalności podmiotów leczniczych. Istnieje także możliwość fakultatywnego finansowania $\mathrm{z}$ budżetu samorządowego gwarantowanych świadczeń zdrowotnych mieszkańcom tworzącym daną wspólnotę samorządową. Z budżetu centralnego są natomiast finansowane niektóre świadczenia opieki zdrowotnej, a także Państwowe Ratownictwo Medyczne.

8 Ustawa z dnia 15 kwietnia 2011 r. o działalności leczniczej (Dz.U. z 2013 r. poz. 217 ze zm.). Określa ona m.in. zasady wykonywania działalności leczniczej oraz zasady funkcjonowania podmiotów wykonujących działalność leczniczą niebędących przedsiębiorcami. Oprócz tego wskazuje na możliwość finansowania podmiotów wykonujących działalność leczniczą z budżetu państwa oraz z budżetów j.s.t. a także z planów finansowych uczelni medycznych.

Dalej: NFZ lub Fundusz.

Dalej: j.s.t.

11 Jednostki samorządu terytorialnego nie są bezpośrednio powiązane z systemem ubezpieczenia zdrowotnego. Są one jednak płatnikami składki na ubezpieczenie zdrowotne za niektórych ubezpieczonych oraz finansują podmioty prowadzące działalność leczniczą oraz prowadzą podmioty wykonujące działalność leczniczą. Organy administracji rządowej pełnią funkcje kontrole w stosunku do Funduszu oraz podmiotów wykonujących działalność leczniczą, a także finansują niektóre świadczenia zdrowotne.

Istnieje także możliwość pozyskiwania środków europejskich na finansowanie ochrony zdrowia pochodzących przede wszystkim z regionalnych programów operacyjnych dla poszczególnych województw na lata 2014-2020, z Programu Operacyjnego Wiedza, Edukacja, Rozwój 2014-2020 oraz Programu Operacyjnego Infrastruktura i Środowisko 2014-2020. Środki finansowe objęte powyższymi programami zostały przekazane z Europejskiego Funduszu Rozwoju Regionalnego, Funduszu Spójności oraz Europejskiego Funduszu Społecznego. 


\section{Niemiecki system finansowania ochrony zdrowia}

Jak to już zostało ustalone wyżej, niemiecki system ochrony zdrowia funkcjonuje w oparciu o ustawowe ubezpieczenie zdrowotne. Jest on elementem systemu ubezpieczenia społecznego, w skład którego wchodzą także ubezpieczenie wypadkowe, emerytalne, od bezrobocia i pielęgnacyjne (§ 1 ust. 1 Księgi Czwartej Kodeksu Socjalnego ${ }^{13}$ ). Podstawą prawną funkcjonowania niemieckiego ustawowego ubezpieczenia zdrowotnego jest Księga Piąta Kodeksu Socjalnego ${ }^{14}$. Zgodnie z § 1 SGB V celem ustawowego ubezpieczenia zdrowotnego jest przywrócenie, utrzymanie i poprawa zdrowia osób ubezpieczonych.

Dla niemieckiego ubezpieczenia zdrowotnego istotne znaczenia ma funkcjonowanie w jego strukturze dwóch rodzajów podmiotów: kas chorych oraz Funduszu Zdrowia. W myśl § 29 ust. 1 SGB IV i § 4 ust. 1 SGB V kasy posiadają status podmiotów prawa publicznego. Odpowiadają za gospodarowanie otrzymanymi środkami publicznymi oraz dokonywanie z nich wydatków. Publicznoprawny status kas świadczy o tym, że regulacje prawnofinansowe determinujące zasady ich funkcjonowania wchodzą w skład publicznego prawa finansowego ${ }^{15}$. Głównym zadaniem kas chorych jest organizacja świadczeń wynikających z zakresu przedmiotowego ustawowego ubezpieczenia zdrowotnego dla swoich członków oraz ich rodzin.

Fundusz Zdrowia został wprowadzony do niemieckiego ubezpieczenia zdrowotnego 1 stycznia 2009 r. Spowodowało to zasadniczą zmianę w zakresie przepływów środków finansowych uzyskanych od członków poszczególnych kas z tytułu obowiązku uiszczania składki ubezpieczeniowej. Obecnie obowiązujące przepisy SGB V wprowadzają redystrybucję przychodów z tytułu składek na ubezpieczenie zdrowotne przez Fun-

13 Sozialgesetzbuch (SGB) Viertes Buch (IV) - Gemeinsame Vorschriften für die Sozialversicherung - vom. 23 Dezember 1976 (BGBl. I S. 3845, dalej: SGB IV).

14 Sozialgesetzbuch (SGB) Fünftesbuch (V) - Gesetzliche Krankenversicherung vom 20 Dezember 1988 (BGBl. I S. 2477, dalej: SGB V).

15 F. Kirchhof, Grundlagen der Finanzierung der Krankenversicherung, [w:] B. Schulin, Handbuch des Sozialversicherungsrechts, Band 1: Krankenversicherungsrecht, München 1994, s. 1319 i n. 
dusz Zdrowia. Istnieje zatem zespolenie sytuacji finansowej wszystkich kas chorych poprzez funkcjonowanie Funduszu Zdrowia ${ }^{16}$.

Świadczeniobiorcom w ramach ustawowego ubezpieczenia zdrowotnego przysługują przede wszystkim świadczenia rzeczowe w postaci m.in. opieki medycznej. Ubezpieczeni mają także prawo do pobierania zasiłku chorobowego (§ 46 SGB V). W niemieckim ustawodawstwie nie istnieje zatem rozdział ubezpieczenia chorobowego od ubezpieczenia zdrowotnego, które w Polsce zostało wyodrębnione z systemu ubezpieczeń społecznych i ma swój odrębny reżim prawny ${ }^{17}$.

\section{Składka na ubezpieczenie zdrowotne w polskim systemie ochrony zdrowia}

Z dokonanych już ustaleń wynika, że w Polsce składka na ubezpieczenie zdrowotne stanowi główne źródło finansowania systemu ochrony zdrowia w Polsce. Planowane przychody z jej tytułu w 2017 r. mają przekroczyć 70 mld $\mathrm{zl}^{18}$. Stanowi ona zatem istotny z fiskalnego punktu widzenia instrument prawnofinansowy pozwalający na gromadzenie środków publicznych przeznaczanych na realizację ściśle określonego zadania publicznego.

Obowiązek uiszczenia składki zdrowotnej wynika z zakresu podmiotowego obowiązkowego ubezpieczenia zdrowotnego. Katalog podmiotów podlegających ubezpieczeniu zdrowotnemu wynika z art. 66 ust. 1 u.ś.o.z. Obowiązkiem ubezpieczeniowym objęci są przede wszystkim: pracownicy, rolnicy, osoby prowadzące pozarolniczą działalność gospodarczą,

16 S. Rixen, Der Sozialversicherungs beitrag als Basis der finanziellen Funktionsfähigkeit der gesetzlichen Krankenversicherung [w:] H. Sodan, Handbuch des Krankenversicherungsrechts, München 2014, s. 1082.

17 Niemieckie ustawowe ubezpieczenie zdrowotne jest także finansowane w istotnej części z budżetu centralnego. Na mocy § 221 ust. 1 SGB V państwo jest zobowiązane do wypłaty na rzecz Funduszu Zdrowia zryczałtowanej rekompensaty wydatków kas chorych na świadczenia pozaubezpieczeniowe w wysokości: 10,5 mld euro za rok 2014, 11,5 mld euro za rok 2015, 14 mld euro za rok 2016, natomiast od 2017 będzie to 14,5 mld euro.

18 Roczny plan finansowy Narodowego Funduszu Zdrowia na rok 2017; www.nfz.gov.pl (dostęp: 15.01.2017 r.). 
osoby wykonujące pracę na podstawie umowy agencyjnej, umowy zlecenia albo innej umowy o świadczenie usług lub osoby z nimi współpracujące, bezrobotni, a także sędziowie i prokuratorzy, emeryci i renciści, osoby duchowne oraz funkcjonariusze służb mundurowych. Z zakresem podmiotowym ściśle związany jest przedmiot składki na ubezpieczenie zdrowotne. Wynika on bowiem z tytułów ubezpieczeniowych, które determinują krąg podmiotów objętych ubezpieczeniem obowiązkowym.

Dla ustalenia składki na ubezpieczenie zdrowotne zasadnicze znaczenie mają zasady obliczania podstawy wymiaru oraz wysokość stawki. W świetle art. 79 ust. 1 u.ś.o.z. dla większości grup ubezpieczonych sposób obliczenia składki zdrowotnej polega na przemnożeniu ustalonej zgodnie z przepisami u.ś.o.z. podstawy wymiaru przez ustawowo wyrażony wskaźnik procentowy (stawkę składki). Podstawa wymiaru składki na ubezpieczenie zdrowotne oraz jej stawka mają zatem zasadniczy wpływ na jej wysokość.

Problematyka ustalania podstawy wymiaru składki zdrowotnej została uregulowana przede wszystkim w art. 81 u.ś.o.z. Treść powoływanego przepisu nawiązuje do zakresu podmiotowego obowiązkowego ubezpieczenia zdrowotnego. W art. 81 ust. 1-10 u.ś.o.z. znajduje się obszerne wyliczenie sposobów określania podstawy wymiaru. Metoda ustalania podstawy wymiaru składki dla danego ubezpieczonego jest uzależniona od tytułu ubezpieczeniowego stanowiącego podstawę do objęcia go obowiązkiem ubezpieczenia $^{19}$.

Podstawa wymiaru składki dla najszerszej zakresowo grupy ubezpieczonych, tj. pracowników, osób wykonujących pracę nakładczą, członków rolniczych spółdzielni produkcyjnych i spółdzielni kółek rolniczych, a także funkcjonariuszy Służby Celnej wynika z art. 18 ust. 1 ustawy

19 Podstawa wymiaru została zatem uregulowana przez ustawodawcę w sposób kazuistyczny. W art. 81 u.ś.o.z. wprost wskazano sposób ustalania podstawy w przypadku każdego tytułu ubezpieczeniowego z osobna. W wielu przypadkach podstawa wymiaru jest sztywno określona przez ustawodawcę poprzez odesłanie do przepisów odrębnych, właściwych ze względu na status ubezpieczonego. Sposób ustalania podstawy wymiaru w odniesieniu do tych ubezpieczonych nie stanowi w praktyce istotnego problemu. 
o systemie ubezpieczeń społecznych ${ }^{20}$. W odniesieniu do tych podmiotów podstawę wymiaru składek na ubezpieczenie społeczne stanowi ich przychód, który został zdefiniowany w art. 4 pkt 9 i 10 u.s.u.s. oraz w przepisach ustawy o podatku dochodowym od osób fizycznych ${ }^{21}$.

Konstrukcja prawna podstawy wymiaru składki zdrowotnej nie jest zatem ukształtowana w przepisach u.ś.o.z. w autonomiczny sposób. Sposób jej obliczania jest uzależniony od konstrukcji prawnej poszczególnych składek na ubezpieczenie społeczne oraz podatku dochodowego od osób fizycznych. Regulacje prawne zawarte w u.s.u.s. i u.p.d.o.f. determinują zatem wysokość składki na ubezpieczenie zdrowotne. Każda ingerencja ustawodawcy w zasady ustalania przychodu w podatku dochodowym od osób fizycznych oraz podstawy wymiaru wymienionych składek na ubezpieczenie społeczne będzie miała zatem wpływ na przychody NFZ z tytułu pobieranej składki zdrowotnej.

Przepisy u.ś.o.z. w nieznacznym zakresie modyfikują jednak zasady ustalania podstawy wymiaru składki funkcjonujące na gruncie regulacji u.s.u.s. Najistotniejsza zmiana sposobu obliczania składek na ubezpieczenie emerytalne i rentowe na potrzeby ustalenia wysokości składki zdrowotnej wynika z niestosowania art. 19 ust. 1 u.s.u.s. Wprowadza on ograniczenie $\mathrm{w}$ zakresie pobierania składek na ubezpieczenie emerytalne i rentowe wówczas, gdy podstawa ich wymiaru w ujęciu rocznym przekroczy wskazane w nim limity, oraz określa procedurę postępowania w takich przypadkach ${ }^{22}$. Po przekroczeniu w ciągu roku kalendarzowego wskazanych limitów składki na ubezpieczenie emerytalne i rentowe nie

20 Ustawa z dnia 13 października 1998 r. o systemie ubezpieczeń społecznych (Dz.U. z 2016 r. poz. 963 ze zm., dalej: u.s.u.s.).

21 Ustawa z dnia 26 lipca 1991 r. o podatku dochodowym od osób fizycznych (Dz.U. z 2016 r. poz. 2032, dalej: u.p.d.o.f.).

22 Zgodnie $\mathrm{z}$ nim roczna podstawa wymiaru składek na ubezpieczenia emerytalne i rentowe osób, o których mowa w art. 6 i 7 (przepisy te określają zakres podmiotowy obowiązkowego ubezpieczenia emerytalnego i rentowego, w skład którego wchodzą również grupy podmiotów wymienione w art. 81 ust. 1 u.ś.o.z.), w danym roku kalendarzowym nie może być wyższa od kwoty odpowiadającej trzydziestokrotności prognozowanego przeciętnego wynagrodzenia miesięcznego w gospodarce narodowej na dany rok kalendarzowy, określonego w ustawie budżetowej, ustawie o prowizorium budżetowym lub ich projektach, jeżeli odpowiednie ustawy nie zostały uchwalone. 
powinny być naliczane, pobierane i odprowadzane na rachunek ZUS, z zastrzeżeniem, że ubezpieczony w dalszym ciągu podlega ubezpieczeniu społecznemu ${ }^{23}$.

Nie w każdym jednak przypadku podstawa wymiaru składki zdrowotnej jest uzależniona od uzyskiwanego przez ubezpieczonego przychodu lub innego świadczenia. Przykładowo, w odniesieniu do osób prowadzących działalność pozarolniczą lub osób z nimi współpracujących podstawę opodatkowania stanowi zadeklarowana kwota pieniężna, która nie może być niższa niż 75\% wysokości przeciętnego miesięcznego wynagrodzenia $\mathrm{w}$ sektorze przedsiębiorstw $\mathrm{w}$ czwartym kwartale roku poprzedniego, włącznie z wypłatami z zysku. Przyjęta przez ustawodawcę konstrukcja podstawy wymiaru składki może w istotny sposób dyskryminować pracowników osiągających wyższe przychody niż 75\% przeciętnego miesięcznego wynagrodzenia w sektorze przedsiębiorstw. Brak jest bowiem racjonalnych przesłanek do tak znaczącego różnicowania sytuacji prawnej ubezpieczonych osiągających podobne korzyści majątkowe, w przypadku których jedyną różnicą jest sposób prowadzenia zawodowej działalności.

Stawka jest drugim obok podstawy wymiaru elementem konstrukcyjnym składki na ubezpieczenie zdrowotne mającym zasadniczy wpływ na jej wysokość. Wysokość stawki składki zdrowotnej wynika zasadniczo z art. 79 ust. 1 u.ś.o.z. i wynosi obecnie 9\% podstawy jej wymiaru. Stawka ta ma zastosowanie przy obliczaniu składek zdrowotnych wszystkich ubezpieczonych, z wyjątkiem rolników i ich domowników (nieprowadzących działów specjalnych produkcji rolnej). W ich przypadku stawka składki wynosi 1 zł od każdego hektara przeliczeniowego użytków rolnych w gospodarstwie rolnym.

Zasadą jest, że składkę na ubezpieczenie zdrowotne opłaca osoba podlegająca obowiązkowemu ubezpieczeniu zdrowotnemu (art. 84 ust. 1 u.ś.o.z.). Dotyczy to w szczególności osób pozostających w stosunku pracy. W ich przypadku składkę oblicza, pobiera z dochodu ubezpieczonego i odprowadza pracodawca będący płatnikiem składki. Nie ponosi on jed-

23 J. Wantoch-Rekowski, Składki na ubezpieczenie społeczne. Konstrukcja i charakter prawny, Toruń 2005, s. 159. 
nak ciężaru ubezpieczonego. Całość składki obciąża jedynie pracownika. Dalsze przepisy u.ś.o.z. wprowadzają szereg wyjątków od powyższej zasady. W związku z tym osoby samodzielnie opłacające składkę zdrowotną stanowią niewielką część ogółu ubezpieczonych. Są to przede wszystkim osoby prowadzące pozarolniczą działalność gospodarczą, rolnicy prowadzący działalność z zakresu działów specjalnych produkcji rolnej oraz niektóre osoby duchowne.

W większości przypadków obowiązek uiszczenia składki zdrowotnej w wysokości 9\% podstawy jej wymiaru nie skutkuje w sposób ostateczny obciążeniem dochodów ubezpieczonego. Na podstawie art. 27b u.p.d.o.f. podatek dochodowy ulega obniżeniu o kwotę składki na ubezpieczenie zdrowotne opłaconej w roku podatkowym bezpośrednio przez podatnika lub pobranej w tym roku przez płatnika, z zastrzeżeniem że kwota składki podlegającej odliczeniu nie może przekroczyć 7,75\% podstawy jej wymiaru określonej na zasadach wynikających z u.ś.o.z. Co do zasady, ubezpieczony będzie zatem ponosił ciężar ubezpieczeniowy w wysokości 1,25\% podstawy wymiaru składki.

W nauce prawa finansowego składka na ubezpieczenie zdrowotne jest uznawana za daninę publiczną ${ }^{24}$. Nie zostało jednak dotychczas jednoznacznie przesądzone jej miejsce w katalogu danin publicznych oraz problem różnic i podobieństw składki zdrowotnej do instytucji podatku.

\section{Składka na ubezpieczenie zdrowotne w niemieckim systemie ochrony zdrowia}

Zgodnie z § 220 ust. 1 SGB V system ubezpieczenia zdrowotnego jest finansowany ze składek, w tym składek dodatkowych oraz pozostałych wpływów. Do elementów konstrukcji prawnej składki w ustawowym ubezpieczeniu zdrowotnym należy zaliczyć przede wszystkim podstawę jej wymiaru oraz stawkę składki. Niemiecki ustawodawca nie wyróżnia w sposób jednoznaczny przedmiotu składki. Jest on bowiem determino-

24 T. Dębowska-Romanowska, Prawo finansowe. Część konstytucyjna wraz z częściq ogólnq, Warszawa 2010, s. 190. 
wany tytułem do obowiązkowego ubezpieczenia oraz przynależnością do danej kasy (członkostwem). Podmiotami zobowiązanymi do ponoszenia kosztów partycypowania w obowiązkowym ubezpieczeniu zdrowotnym w postaci uiszczania składki są ubezpieczeni będący członkami danej kasy.

Osoby, dla których tytułem ubezpieczeniowym jest zatrudnienie, nie opłacają z własnych środków całości składki. Są oni zobowiązani do ponoszenia jedynie połowy jej kosztów. W myśl § 249 ust. 1 SGB V połowę kosztów składek ponosi pracodawca. Tego rodzaju sposób finansowania składki na ubezpieczenie zdrowotne osób zatrudnionych dotyczy jedynie składki obliczonej przy zastosowaniu ogólnej stawki, o której mowa w § 241 SGB V. Pracodawca nie jest zobowiązany do ponoszenia kosztów składek obliczanych według stawki dodatkowej wprowadzonej przez kasę chorych na podstawie § 242 SGB V. W większości przypadków podmiot zobowiązany do uiszczenia składki ze swoich przychodów nie jest tożsamy z podmiotem, na którym ciąży obowiązek jej odprowadzenia. $\mathrm{W}$ procedurze poboru składki ubezpieczeniowej istotne znaczenie ma zatem instytucja płatnika.

W konstrukcji prawnej omawianej składki ustawowego ubezpieczenia zdrowotnego występują także zwolnienia z obowiązku jej uiszczania. Podstawą do zwolnienia jest przekroczenie określonej ustawowo rocznej granicy dochodu z tytułu zatrudnienia. Wówczas podmiot zatrudniony może ubezpieczyć się w danej kasie chorych dobrowolnie ${ }^{25}$. Obowiązkiem opłacania składki zdrowotnej nie są także obciążeni członkowie rodziny ubezpieczonego, korzystający z jego ochrony ubezpieczeniowej ${ }^{26}$.

Na podobnych zasadach została również ukształtowana sytuacja niektórych osób pobierających emeryturę. Połowę składki obliczanej na podstawie ogólnej stawki ponosi instytucja ubezpieczeniowa wypłacająca świadczenia (§ 249a SGB V). Pozostała jej część finansowana jest ze środków ubezpieczonego członka kasy.

25 Konsekwencją tego jest wynikający z § 257 ust. 1 SGB V obowiązek po stronie pracodawcy do wpłaty pracownikowi tzw. dopłaty do składki ubezpieczeniowej w ubezpieczeniu dobrowolnym w kwocie, którą pracodawca byłby zobowiązany do uiszczenia w ramach ubezpieczenia obowiązkowego.

26 R. Mack, Komentarz do § 220, [w:] K. Engelmann, R. Schlegel (red.), Sozialgesetzbuch Fünftes Buch - Gesetzliche Krankenversicherung, Saarbrücken 2012, s. 3248. 
Podstawa wymiaru składki zdrowotnej dla wszystkich ubezpieczonych została kazuistycznie uregulowana w przepisach SGB V. Zgodnie z § 226 ust. 1 SGB V dla osób zatrudnionych, którzy stanowią największą grupę społeczną w strukturze ubezpieczenia zdrowotnego, podstawą wymiaru składki jest wynagrodzenie otrzymywane z tytułu zatrudnienia.

Przepisy SGB V nie zawierają na potrzeby obliczenia wysokości podstawy wymiaru składki zdrowotnej własnej definicji wynagrodzenia. W tym zakresie odsyłają do stosowania regulacji prawnych wynikających z SGB IV ${ }^{27}$. W myśl § 14 SGB IV przez wynagrodzenie należy rozumieć wszystkie bieżące lub jednorazowe przychody pochodzące z tytułu jednej aktywności zawodowej (zajęcia) bez względu na nazwę oraz formę jej wykonywania. Wynagrodzenie stanowiące podstawę wymiaru składki obejmuje także należny od niego podatek dochodowy oraz składki na inne rodzaje ubezpieczeń społecznych. Podstawa wymiaru składki w ustawowym ubezpieczeniu zdrowotnym jest zbliżona do podstawy wymiaru w niemieckim podatku dochodowym. Nieznaczne różnice wynikają jedynie z przepisów wykonawczych wydanych na podstawie § 14 SGB IV.

Charakterystycznym elementem zasad ustalania podstawy wymiaru jest istnienie górnej granicy uzyskiwanych przychodów. Jej osiągnięcie powoduje brak obowiązku uiszczania składki od części wynagrodzenia z tytułu zatrudnienia przekraczającego ustawowy próg. Ograniczenie to wynika z § 223 ust. 3 SGB V. Zawiera on szczegółowe zasady obliczania maksymalnej wysokości podstawy wymiaru składki. Skutkiem jego obowiązywania jest zmniejszenie ciężaru ubezpieczeniowego tych członków kas, którzy uzyskują najwyższe przychody. Istnienie górnej granicy podstawy wymiaru ma swoje uzasadnienie przede wszystkim w tym, że zakres świadczeń przysługujących w ramach systemu ubezpieczeniowego nie jest w żaden sposób związany z wysokością uiszczanej składki zdrowotnej.

Jako drugi element konstrukcji prawnej składki mający zasadniczy wpływ na zakres ponoszonego ciężaru ubezpieczeniowego należy wskazać stawkę składki. Zgodnie z § 241 SGB V jej wysokość wynosi dla

27 H. Marburger, Komentarz do § 226 [w] W. Eichenhofer, U. Wenner (red.), Kommentar zum Sozialgesetbuch V, Köln 2013, s. 1641. 
większości ubezpieczonych $14,6 \%$ podstawy wymiaru ${ }^{28}$. Istnieje także możliwość wprowadzenia dodatkowej stawki składki zdrowotnej. Kasy chorych są uprawnione do pobierania składki powiększonej o stawkę dodatkową od swoich członków. Na podstawie § 242 ust. 1 SGB V ustalają one we własnym zakresie jej wysokość. Przesłanką do wprowadzenia dodatkowego obciążenia składkowego jest niepokrycie zapotrzebowania danej kasy ze środków otrzymanych z Funduszu Zdrowia. Składka w stawce dodatkowej powinna być uzależniona od wysokości dochodu członka kasy. Wysokość stawki składki powinna także umożliwiać pokrycie przewidywanych na dany rok wydatków ze środków pochodzących z dotacji z Funduszu Zdrowia powiększonych o wpływy ze składki dodatkowej ${ }^{29}$.

W niemieckim ustawowym ubezpieczeniu zdrowotnym stawka składki zdrowotnej o stałym (liniowym) charakterze oraz podstawa wymiaru uzależniona od zdolności płatniczej członka kasy powodują istnienie zróżnicowanego ciężaru ubezpieczeniowego. Każdy członek kasy ponosi koszty ochrony ubezpieczeniowej w indywidualnie ustalonej wysokości determinowanej osiąganymi przez niego przychodami. Przysługuje mu przy tym ten sam zakres świadczeń gwarantowanych w ramach ustawowego ubezpieczenia zdrowotnego w zakresie ilościowym i jakościowym. Nie istnieje zatem związek pomiędzy wysokością uiszczanej składki zdrowotnej a zakresem świadczeń przysługujących członkowi kasy.

Zgodnie z § 252 ust. 1 SGB V zobowiązanym do faktycznego odprowadzenia składki jest ten, kto ponosi jej koszty. Przepisy SGB wpro-

28 Stawka w wysokości 14,6\% podstaw wymiaru składki nie będzie miała zastosowania wobec wszystkich ubezpieczonych. Przepisy SGB wprowadzają dla niektórych ubezpieczonych możliwość modyfikacji jej wysokości. Jedynie przykładowo należy wskazać, że w przypadku członków kas nieposiadających roszczeń wobec ustawowego ubezpieczenia zdrowotnego obowiązuje obniżona stawka składki, która na podstawie $\S 243$ SGB V wynosi $14 \%$ podstawy wymiaru.

29 Jeżeli w trakcie roku budżetowego okaże się, że wpływy kasy nie są wystarczające na pokrycie wydatków, należy podnieść stawkę składki dodatkowej. Ponadto, kasa wprowadzająca stawkę dodatkową zobowiązana jest dokonać zgłoszenia do Stowarzyszenia Kas Chorych (Bund der Krankenkassen), które prowadzi listę kas podnoszących stawkę dodatkową z informacją o jej wysokości. 
wadzają jednak szereg uregulowanych w sposób kazuistyczny wyjątków od powołanej zasady § 253-256 SGB V), które powodują, że do większości ubezpieczonych wymieniona zasada nie ma zastosowania ${ }^{30}$.

Konstrukcja prawna składki zdrowotnej, w tym zasady ustalania podstawy jej wymiaru oraz funkcjonowanie stawki dodatkowej, wskazuje, że w ustawowym ubezpieczeniu zdrowotnym obowiązuje tzw. system repartycyjny. Polega on na tym, że z pobranych składek ubezpieczeniowych muszą zostać opłacone świadczenia przysługujące z tytułu członkostwa w kasie chorych ${ }^{31}$. Regulacje prawne zawarte w SGB V nie wskazują wprost na istnienie $\mathrm{w}$ niemieckim ubezpieczeniu zdrowotnym sytemu repartycyjnego. W literaturze przedmiotu podkreśla się jednak, że system repartycyjny stanowi podstawę funkcjonowania ustawowego ubezpieczenia zdrowotnego ${ }^{32}$.

W literaturze prawa niemieckiego przyjmuje się, że składka na ubezpieczenie zdrowotne jest daniną publiczną ${ }^{33}$. Wskazuje się także, że pomiędzy składką zdrowotną a instytucją podatku istnieją istotne podobieństwa Mimo to jest ona uznawana za odrębną daninę publiczną, do której nie zawsze możliwe jest stosowanie dorobku nauki prawa podatkowego ${ }^{34}$. Podkreśla się, że istotną różnicą pomiędzy składką w ustawowym ubezpieczeniu zdrowotnym a podatkiem jest to, iż składka wnoszona jest na konkretny cel. Z jej wpływów finansowane są konkretne rodzaje zadań publicznych.

30 H. Peters, Komentarz do § 252, [w:] K. Engelmann, R. Schlegel (red.), Sozialgesetzbuch Fünftes..., s. 3509.

31 F. Hase, Versicherungsprinzip und sozialer Ausgleich. Eine Studie zu den verfassungsrechtlichen Grundlagen des deutschen Sozialversicherungsrechts, Tübingen 2000, s. 309.

32 S. Rixen, Der Sozialversicherungs beitrag..., [w:] H. Sodan, Handbuch des Krankenversicherungsrechts..., s. 1079.

33 R. Mack, Komentarz do § 220, [w:] K. Engelmann, R. Schlegel (red.), Sozialgesetzbuch Fünftes Buch..., s. 3249.

34 S. Rixen, Der Sozialversicherungs beitrag..., [w:] H. Sodan, Handbuch des Krankenversicherungsrechts..., s. 1072. 


\section{Różnice i podobieństwa w konstrukcji polskiej i niemieckiej składki zdrowotnej}

Na podstawie ustalonych wyżej elementów konstrukcji prawnej składki funkcjonującej w niemieckim ustawowym ubezpieczeniu zdrowotnym oraz składki w polskim modelu ochrony zdrowia opartym o powszechne ubezpieczenie zdrowotne interesującym problemem jest ustalenie różnic i podobieństw zachodzących pomiędzy badanymi instrumentami prawnofinansowymi. Treść normatywna polskich i niemieckich regulacji prawnych w tym zakresie wskazuje na następujące podobieństwa.

Po pierwsze, składki zdrowotne w obu systemach stanowią najistotniejsze źródło finansowania świadczeń przysługujących w ramach ubezpieczenia zdrowotnego. Ich cel ma charakter fiskalny. Wpływy z tytułu uiszczania składek zapewniają możliwość realizacji zadań publicznych z zakresu ochrony zdrowia. Skutkiem obowiązku opłacania składki jest przymusowe przesunięcie prywatnych środków na rzecz instytucji publicznoprawnych odpowiedzialnych za organizację świadczeń zdrowotnych w ramach publicznego systemu ochrony zdrowia.

Po drugie, ciężar ubezpieczeniowy w postaci ponoszenia kosztów uiszczania składki nie został rozłożony w sposób równomierny na wszystkich ubezpieczonych. W obu przypadkach jego zakres jest uzależniony od indywidualnej zdolności płatniczej ubezpieczonego. O wysokości składki zdrowotnej decyduje zasadniczo wielkość uzyskiwanych przychodów lub innego rodzaju świadczeń. Nie istnieje jedna składka dla wszystkich ubezpieczonych. Przyczyniają się oni w różnym stopniu do finansowania systemu, w którym uczestniczą. Niektórzy ubezpieczeni w ogóle nie ponoszą ciężaru ubezpieczeniowego z uwagi na liczne zwolnienia w konstrukcji polskiej i niemieckiej składki zdrowotnej. Istotne znaczenia mają przy tym jednolite zasady uzyskiwania świadczeń zdrowotnych. Wysokość obciążenia składkowego nie ma wpływu na ilościowy i jakościowy zakres ochrony ubezpieczeniowej. Jest to skutkiem funkcjonowania zasady solidarności społecznej, której podstawę normatywną w ustawowym ubezpieczeniu zdrowotnym stanowi § 3 ust. 1 SGB V, a w polskim ustawodawstwie art. 65 pkt 1 u.ś.o.z. Istota tej zasady spro- 
wadza się do finansowania systemu ochrony zdrowia przez ubezpieczonych według ich indywidualnych możliwości i nie jest uzależniona od zakresu przysługujących świadczeń oraz ryzyka ubezpieczeniowego, które w każdym przypadku jest inne.

Po trzecie, zbliżony jest także sposób obliczania wysokości składki ubezpieczeniowej. W obu przypadkach jest ona bowiem uzależniona od wysokości przychodów uzyskiwanych z wszelkiego rodzaju aktywności zawodowej ubezpieczonych, chociaż polski i niemiecki ustawodawca przewiduje od tego szereg wyjątków. Podobieństwa wynikają także z techniki legislacyjnej w zakresie określania podstawy wymiaru składek. Polskie i niemieckie regulacje prawne w zakresie ubezpieczenia zdrowotnego w większości przypadków nie zawierają autonomicznych zasad ustalania zakresu otrzymywanych przez ubezpieczonego świadczeń, stanowiących elementy składowe podstawy wymiaru składki oraz obliczania ich wysokości. W ich miejsce wprowadzono odesłanie do zasad ustalania podstawy wymiaru składek w innych pokrewnych systemach ubezpieczeniowych.

Po czwarte, częściowe podobieństwo występuje także w zakresie stawki składki zdrowotnej. Stawka w konstrukcji prawnej polskiej i niemieckiej składki ma charakter stały (liniowy). Jej wysokość nie ulega modyfikacji wraz ze zmianą wielkości podstawy opodatkowania. Nie powoduje to zatem dodatkowego obciążenia tych grup ubezpieczonych, na których ciąży największy obowiązek ponoszenia kosztów opłacania składki z uwagi na znaczną wysokość ich przychodów stanowiących podstawę wymiaru składki. Uiszczają oni bowiem składkę ubezpieczeniową w takiej samej stawce, ale w różnej wysokości. Wprowadzenie stawki progresywnej powodowałoby zbyt daleko idące dysproporcje pomiędzy zakresem obciążeń publicznoprawnych z tytułu obowiązkowego ubezpieczenia zdrowotnego przy jednolitym zakresie przysługujących świadczeń.

Po piąte, zbliżone są techniczne zasady opłacania składki. W obu rodzajach ubezpieczenia zasadą jest, że zobowiązanym do odprowadzenia należnej składki jest podmiot, na którym ciąży koszt jej poniesienia. Polskie i niemieckie regulacje prawne przewidują jednak szereg wyjątków w tym zakresie. Najistotniejszym z nich jest obowiązek odprowadzenia 
całości składki zdrowotnej przez pracodawcę za pracownika. Stanowi to przejaw dbałości o nadmierne nieobciążanie pracowników proceduralnymi obowiązkami związanymi z obliczeniem i przekazaniem składki w prawidłowej wysokości na rachunek właściwego podmiotu publicznego.

Po szóste, konstrukcja prawna składek w polskim i niemieckim ubezpieczeniu zdrowotnym determinuje ich charakter prawny. Są one zaliczane do katalogu danin publicznoprawnych. Jak to już ustalono, w literaturze prawa niemieckiego wskazuje się, że tego rodzaju danina nie może być utożsamiana z instytucją podatku. W polskiej literaturze prawa finansowego problematyka charakteru prawnego składki zdrowotnej nie jest szeroko poruszana. Odrębność składki od podatku nie została w sposób jednoznaczny przesądzona. W ocenie autora niniejszego opracowania składka na ubezpieczenie zdrowotne jest samodzielną daniną publiczną, której nie można utożsamiać z podatkiem. Nosi ona jedynie te cechy podatku, które są wspólne wszystkim daninom publicznoprawnym. W przeciwieństwie do podatków ma ona charakter odpłatny i jest świadczeniem o charakterze celowym ${ }^{35}$.

Mimo licznych podobieństw polska i niemiecka wersja składki na ubezpieczenie zdrowotne wynikające $\mathrm{z}$ regulacji prawnych zawartych w przepisach Piątej Księgi Kodeksu Socjalnego oraz ustawy o świadczeniach opieki zdrowotnej finansowanych ze środków publicznych zawierają liczne różnice. Do najważniejszych z nich należy zaliczyć te, które mają istotny wpływ na zakres obciążenia daniną publiczną.

Po pierwsze, jest to zróżnicowanie sposobu ustalania podstawy wymiaru składki. Jak to już zostało ustalone, składka zdrowotna w niemieckim ubezpieczeniu zdrowotnym jest w większości przypadków determinowana wysokością uzyskiwanych przychodów. Podobne zasady przewidują regulacje wynikające u.ś.o.z. Przepisy SGB V wprowadzają jednak kwotowe ograniczenia podstawy wymiaru składki powodujące brak obowiązku jej uiszczania od przychodów przekraczających ustawowy próg. Zapobiega to istnieniu skrajnego zróżnicowania w rozłożeniu obowiązku

35 Zob. szerzej: P. Lenio, Charakter prawny składki na ubezpieczenie zdrowotne jako źródła finansowania świadczeń opieki zdrowotnej, „Przegląd Prawa i Administracji” 2014, nr 97, s. 99 i n. 
partycypowania w kosztach ubezpieczenia zdrowotnego w postaci uiszczania składki. Mimo że niemiecka wersja ubezpieczenia zdrowotnego (tak jak polski system ochrony zdrowia) opiera się o zasadę solidarności społecznej, zdecydowano się jednak ograniczyć wysokość uiszczanej przez ubezpieczonych składki. W ocenie autora opracowania, funkcjonowanie zasady solidarności społecznej w aspekcie finansowania modelu ochrony zdrowia nie stoi na przeszkodzie w ustawowym ograniczeniu obowiązku składkowego w odniesieniu do ubezpieczonych, którzy osiągają bardzo wysokie przychody. Nadto, zasada solidarności społecznej, o której mowa w art. 65 pkt 1 u.ś.o.z., nie może stanowić samoistnego uzasadnienia dla tak istotnego zróżnicowania obowiązkiem ponoszenia składki na ubezpieczenie zdrowotne.

Po drugie, odmienny zakres obciążenia składką na ubezpieczenie zdrowotne w badanych systemach prawnych wynika z zastosowania w ich konstrukcji stawki o zróżnicowanej wysokości. Różna wysokość wskaźników procentowych wynika przede wszystkim z odmiennego zakresu świadczeń przysługujących w ramach obu systemów ubezpieczeniowych. Niemieckie ubezpieczenie ma bowiem szerszy przedmiotowo zakres. W jego ramach przysługuje także członkowi danej kasy roszczenie o wypłatę zasiłku chorobowego. Częściowo można w tym upatrywać przyczyn istotnej różnicy między wysokością stawek w konstrukcji polskiej i niemieckiej składki zdrowotnej. Wysokość stawki składki determinuje zakres obciążenia daniną publiczną ${ }^{36}$.

Po trzecie, w niemieckim ubezpieczeniu zdrowotnym na pracodawcy ciąży obowiązek ponoszenia kosztów połowy należnej składki. Polska wersja składki nie przewiduje bezpośredniego partycypowania pracodawcy w kosztach uiszczania składki zdrowotnej, która w całości obciąża ubezpieczonego pracownika. Nie może to jednak oznaczać, że pracownicy ubezpieczeni w polskim systemie ochrony zdrowia są w gorszej sytuacji niż zatrudnieni objęci niemieckim systemem. Przeniesienie części ciężaru ubezpieczeniowego na pracodawcę mogłoby mieć jedynie charakter for-

36 Oceniając wysokość stawki składki zdrowotnej, należy mieć na uwadze całość obciążeń fiskalnych funkcjonujących w przyjętym przez danego ustawodawcę systemie danin publicznych. Wykracza to jednak poza ramy przedmiotowe niniejszego opracowania. 
malny. Doszłoby wówczas do zmiany wysokości wynagrodzenia brutto pracownika w celu rekompensaty kosztów opłacania składki. Wysokość otrzymywanego wynagrodzenia netto pozostałaby na tym samym poziomie.

Po czwarte, zasady funkcjonowania i finansowania polskiej wersji systemu ubezpieczenia zdrowotnego nie dopuszczają możliwości ingerowania innych organów poza ustawodawcą w konstrukcję podstawowych elementów składki zdrowotnej, a w szczególności jej stawki. Podmioty funkcjonujące $w$ ramach powszechnego ubezpieczenia zdrowotnego nie są uprawnione do modyfikacji ustawowo określonej stawki nawet wówczas, gdy przychody uzyskiwane z jej tytułu nie zapewniają prawidłowej realizacji zadań nich nałożonych.

Po piąte, w polskim systemie ochrony zdrowia istnieje możliwość odliczenia części kwoty składki zdrowotnej uiszczonej w danym roku podatkowym od podatku dochodowego od osób fizycznych. Brak jest analogicznego rozwiązania $\mathrm{w}$ niemieckim ustawowym ubezpieczeniu zdrowotnym. Wprowadzenie możliwości odliczenia części składki zdrowotnej od podatku dochodowego ma jednak uzasadnione. Z chwilą wejścia w życie reformy systemu ochrony zdrowia z $1997 \mathrm{r}$. wprowadzono do polskiego porządku prawnego składkę na zdrowotną jako nową daninę publiczną. Nałożenie obowiązku opłacania składki mogło spowodować znaczący wzrost obciążenia daninowego poszczególnych grup społecznych (przede wszystkim pracowników i zleceniobiorców). Stąd zdecydowano się na wprowadzenie przedmiotowego odliczenia.

\section{Wnioski}

Podobieństwa elementów konstrukcji prawnej składki w polskim ubezpieczeniu zdrowotnym do składki w niemieckim ustawowym ubezpieczeniu zdrowotnym wynikają przede wszystkim z przyjętego modelu ochrony zdrowia. Badane systemy zdrowotne $\mathrm{w}$ swych założeniach oparte są o tzw. model Bismarcka. Niemieckie ubezpieczenie zdrowotne stanowi kontynuację wprowadzonego pod koniec XIX w. ustawodawstwa socjalnego mimo, że nie funkcjonuje już ono w wersji pierwotnej. 
Przyjęcie zbliżonego w swych założeniach systemu organizacji ochrony zdrowia powoduje ustalenie podobnych zasad jego finansowania. Cechą charakterystyczną każdego modelu ubezpieczeniowego jest funkcjonowanie w jego ramach składki ubezpieczeniowej. Stanowi ona udział ubezpieczonego w kosztach funkcjonowania systemu, przez które należy rozumieć finansowanie określonego rodzaju świadczeń na skutek wystąpienia ryzyka ubezpieczeniowego. Od szczegółowych rozwiązań legislacyjnych zależy konstrukcja poszczególnych elementów składki. Jest ona także uzależniona od funkcjonującego systemu danin publicznych, którego ma się stać elementem oraz przepisów rangi konstytucyjnej determinujących zasady wprowadzania i funkcjonowania obciążeń publicznoprawnych. Uzasadnione wydaje się zatem twierdzenie, iż nie jest możliwe przejęcie rozwiązań legislacyjnych funkcjonujących w obcym ustawodawstwie bez uwzględnienia specyfiki krajowego porządku prawnego.

W świetle dokonanych w niniejszym opracowaniu ustaleń można jednak sformułować wnioski de lege ferenda. Przede wszystkim uzasadnione wydaje się ustawowe ograniczenie maksymalnej wysokości podstawy wymiaru składki zdrowotnej w ujęciu rocznym przede wszystkim w odniesieniu do ubezpieczonych, dla których jest ona ustalana jako osiągnięty w danym miesiącu przychód. Doprowadziłoby to do zmniejszenia zróżnicowania w zakresie obowiązku partycypowania w kosztach funkcjonowania powszechnego ubezpieczenia zdrowotnego przez poszczególnych ubezpieczonych, w szczególności pracowników i zleceniobiorców. Z drugiej jednak strony zmniejszyłoby to przychody Narodowego Funduszu Zdrowia z tytułu składki zdrowotnej. W ocenie autora opracowania istnieją jednak sposoby zwiększenia wpływów Funduszu z tego tytułu. Uzasadnione wydaje się bowiem uzależnienie wysokości składki zdrowotnej osób prowadzących działalność pozarolniczą od uzyskiwanych przychodów lub dochodów (nie miałoby to jednocześnie istotnego wpływu na zakres ich obciążeń daninowych z uwagi na możliwość odliczenia części składki zdrowotnej od kwoty podatku dochodowego).

Zaznaczyć jednak należy, że ingerencja ustawodawcy w zasady ustalania wysokości składki na ubezpieczenie zdrowotne będzie skutkować zmianą wysokości wpływów do budżetu państwa z tytułu podatku docho- 
dowego od osób fizycznych. W przypadku przedsiębiorców zwiększenie obowiązku składkowego spowoduje możliwość dokonania odliczenia części składki zdrowotnej od podatku dochodowego w wyższej kwocie. Zwiększenie przychodów NFZ z tytułu składki zdrowotnej zależy zatem od preferencji ustawodawcy w zakresie kierunków finansowania zadań publicznych.

Istotną różnicą jest pomiędzy przedstawionymi daninami publicznymi jest możliwość ustalania wysokości stawki dodatkowej przez kasy chorych. Nadanie NFZ uprawnień do modyfikacji wysokości stawki składki w przypadku, gdy wpływy z tytułu składki zdrowotnej nie są wystarczające na pokrycie wydatków Funduszu, nie wydaje się jednak możliwe. Zgodnie z art. 217 Konstytucji RP nakładanie danin publicznych musi następować w drodze ustawy, a nie na podstawie autonomicznej decyzji organów administracji państwowej.

\section{Bibliografia:}

Dębowska-Romanowska T., Prawo finansowe. Część konstytucyjna wraz z częściq ogólnq, C.H. Beck, Warszawa 2010.

Dziubińska-Michalewicz M., Systemy ubezpieczeń zdrowotnych w wybranych krajach Unii Europejskiej (Francji, RFN, Szwecji, Wielkiej Brytanii). Raport nr 168, http://biurose.sejm.gov.pl/teksty/r-168.htm.

Eichenhofer W., Wenner U. (red.), Kommentar zum Sozialgesetbuch V, Luchterhand Verlag, Köln 2013.

Engelmann K., Schlegel R. (red.), Sozialgesetzbuch Fünftes Buch - Gesetzliche Krankenversicherung, Juris, Saarbrücken 2012.

Hase F., Versicherungsprinzip und sozialer Ausgleich. Eine Studie zu den verfassungsrechtlichen Grundlagen des deutschen Sozialversicherungsrechts, Verlag Mohr Siebeck, Tübingen 2000.

Kirchhof F., Grundlagen der Finanzierung der Krankenversicherung, [w:] B. Schulin, Handbuch des Sozialversicherungsrechts, Band 1: Krankenversicherungsrecht, C.H. Beck, München 1994.

Lenio P., Charakter prawny składki na ubezpieczenie zdrowotne jako źródła finansowania świadczeń opieki zdrowotnej, „Przegląd Prawa i Administracji” 2014, nr 97, s. 99-115. 
Paweł Lenio

Rixen S., Der Sozialversicherungs beitrag als Basis der finanziellen Funktionsfähigkeit der gesetzlichen Krankenversicherung, [w:] H. Sodan (red.), Handbuch des Krankenversicherungsrechts, C.H. Beck, München 2014.

Wantoch-Rekowski J., Składki na ubezpieczenie społeczne. Konstrukcja i charakter prawny, TNOiK, Toruń 2005. 